\title{
(1) \\ CrossMark \\ A comparison of linezolid lung tissue concentrations among patients with drug-resistant tuberculosis
}

\author{
To the Editor:
}

Linezolid has become a frequent component of treatment regimens for drug-resistant tuberculosis and is a group $\mathrm{C}$ drug in the latest World Health Organization treatment guidelines [1]. However, linezolid has a narrow therapeutic index and there is no consensus on the optimal dose for patients with tuberculosis $[2,3]$. A better understanding of lung tissue penetration could provide insight into ideal dosing and the utility of linezolid in patients with severe lung lesions. To evaluate target site lung concentrations of linezolid, we utilised the technique of microdialysis, which facilitates the measurement of unbound (pharmacologically active) extracellular drug concentrations at the site of disease.

Consenting patients with culture-confirmed tuberculosis, already receiving linezolid and undergoing adjunctive surgical resection in Tbilisi, Georgia were enrolled [4, 5]. Patients fasted overnight and received linezolid two hours before surgery. Serum samples were collected immediately before and 1,4 and $8 \mathrm{~h}$ after linezolid administration and at the time of resection. Microdialysis was performed ex vivo on resected lung, immediately after surgical removal. Guided by visual and manual inspection, two semi-permeable microdialysis probes were inserted into both diseased and non-diseased lung. The first probe was placed in the centre of the resected lesion and the second probe was placed in the non-diseased surrounding lung tissue. Four different concentrations of linezolid $\left(0.5,5,25\right.$ and $\left.100 \mu \mathrm{g} \cdot \mathrm{mL}^{-1}\right)$ were each infused for every patient for $\sim 35 \mathrm{~min}$, at a rate of $1 \mu \mathrm{g} \cdot \mathrm{min}^{-1}$, and the recovered fluid "dialysate" was collected. Drug concentrations were measured at the University of Florida Infectious Diseases Pharmacokinetics Laboratory, using a validated liquid chromatography-tandem mass spectrometry assay. The six-point standard curves ranged from $0.3-30.0 \mu \mathrm{g} \cdot \mathrm{mL}^{-1}$ with linearity extending above and below this range; recovery of linezolid from human plasma was approximately $87 \%$. A modification of this assay (range $0.3-$ $120 \mu \mathrm{g} \cdot \mathrm{mL}^{-1}$ ) was used for dialysate samples. Non-compartmental pharmacokinetic analysis was performed. The fraction of the dose absorbed was assumed to be 1 for analysis. Free linezolid serum concentrations were calculated by multiplying the measured serum linezolid concentration by the reported rate of protein binding of $31 \%$ (serum concentration $\times 0.31$ ) [6]. In comparing free serum and tissue drug concentrations, the serum concentration from the time of surgical resection was used. Pre-operative chest computed tomography (CT) scans, when available, were reviewed independently by radiologists. Tissue cultures were performed on resected lung tissues.

Eight male patients with a median age of 34 years were enrolled. The median body mass index was $23.8 \mathrm{~kg} \cdot \mathrm{m}^{-2}$, creatinine clearance was $104.2 \mathrm{~mL} \cdot \mathrm{min}^{-1}$ and albumin was $4.3 \mathrm{~g} \cdot \mathrm{dL}^{-1}$. Five patients had multidrug-resistant and three had extensively drug-resistant tuberculosis. Half of the patients were re-treatment cases. At the time of resection, patients were receiving linezolid for a median duration of 194 days. All patients were receiving a linezolid dose of $600 \mathrm{mg}$ once daily and the median linezolid dose by weight was $8.3 \mathrm{mg} \cdot \mathrm{kg}^{-1}$ (range $7.6-9.9 \mathrm{mg} \cdot \mathrm{kg}^{-1}$ ). On chest CT scans, five patients showed a nodule; two, a cavity; and one, an infiltrate as the predominant lesion. All lung tissue cultures were negative for Mycobacterium tuberculosis.

Among the eight patients receiving linezolid, the median maximum serum concentration $\left(12.98 \mu \mathrm{g} \cdot \mathrm{mL}^{-1}\right)$, area under the curve (AUC) from time zero to infinity $\left(104 \mathrm{~h} \cdot \mu \mathrm{g} \cdot \mathrm{mL}^{-1}\right)$, length of time that the drug was present at the maximum concentration in serum $(2 \mathrm{~h})$; and half-life $(4.5 \mathrm{~h})$ were similar to those reported

@ERSpublications

Among TB patients undergoing surgical resection, linezolid concentrations in lung tissue were half of serum values http://ow.ly/Anlb30hEpW4

Cite this article as: Kempker RR, Heinrichs MT, Nikolaishvili K, et al. A comparison of linezolid lung tissue concentrations among patients with drug-resistant tuberculosis. Eur Respir J 2018; 51: 1702166 [https://doi.org/10.1183/13993003.02166-2017]. 
in the literature. The median free (non-protein-bound) linezolid concentration in diseased lung tissue was $3.57 \mu \mathrm{g} \cdot \mathrm{mL}^{-1}$ (range $0.81-7.09 \mu \mathrm{g} \cdot \mathrm{mL}^{-1}$ ), and in non-diseased lung, it was $3.85 \mu \mathrm{g} \cdot \mathrm{mL}^{-1}$ (range $1.17-10.24$ $\left.\mu \mathrm{g} \cdot \mathrm{mL}^{-1}\right)$, with no significant difference between the two $(\mathrm{p}=0.73)$. There was a nonsignificant trend towards higher linezolid lung tissue concentrations in new versus previously treated patients in both diseased (4.68 versus $2.81 \mu \mathrm{g} \cdot \mathrm{mL}^{-1} ; \mathrm{p}=0.28$ ) and non-diseased lung tissue (5.42 versus $2.92 \mu \mathrm{g} \cdot \mathrm{mL}^{-1}$; $\mathrm{p}=0.27$ ). The median diseased tissue/serum linezolid concentration was 0.49 (range 0.18-0.92) (table 1).

Our results indicate relatively low lung tissue penetration of linezolid in both diseased and non-diseased lung tissue, among patients with multidrug-resistant tuberculosis. In all patients, the free linezolid concentration in diseased lung was lower than the serum concentrations, as was the case for seven out of eight patients with regards to non-diseased lung compared to serum. Lung tissue penetration of linezolid (lung/serum ratio 0.49) was lower than we what we have previously shown for levofloxacin (1.33) and pyrazinamide $(0.77)$, utilising the same microdialysis method $[5,7]$. The trend towards lower lung tissue concentrations of linezolid in re-treatment tuberculosis cases warrants further study. This finding suggests that accumulating lung damage from multiple episodes of tuberculosis might result in a change in lung tissue architecture, thereby reducing drug penetration.

The clinical significance of this relatively low drug penetration of linezolid into lung tissue is unclear. Although linezolid minimum inhibitory concentration (MIC) testing was not performed, the free linezolid drug concentrations in the lung were higher than the suggested epidemiological MIC cut-off of $0.5 \mathrm{mg} \cdot \mathrm{L}^{-1}$ in all cases, and above the generally accepted clinical susceptibility breakpoint of $1 \mathrm{mg} \cdot \mathrm{L}^{-1}$ in seven patients [8]. In addition, in seven out of eight patients, the linezolid concentration in diseased lung was higher than the mutant prevention concentration found in 90\% (MPC90) of M. tuberculosis isolates in one study that used a concentration of $1.2 \mathrm{mg} \cdot \mathrm{L}^{-1}$ [9]. The one patient with a linezolid concentration in diseased lung of $<1 \mathrm{mg} \cdot \mathrm{L}^{-1}$ received the lowest weight-based dose, and correspondingly had the lowest serum drug concentration. In addition, all patients had negative tissue cultures (half of the patients were also receiving bedaquiline), which is in contrast to the high rates of positive lung tissue cultures we found among patients with multidrug-resistant tuberculosis receiving traditional second-line drug regimens [7, 10]. While our results suggest that once a day $600 \mathrm{mg}$ dosing could provide adequate lung tissue concentrations, they also urge caution when using doses less than $600 \mathrm{mg}$.

Our results build on prior research that describes tissue penetration of second-line anti-tuberculosis drugs, utilising the method of microdialysis, which allows for the measurement of free "active" drug at the site of disease. They also add to the scant literature on lung penetration of linezolid. The only prior report of linezolid lung tissue concentrations to our knowledge, was in a paediatric patient with multidrug-resistant tuberculosis who underwent lung resection surgery. This patient received their last dose of linezolid $36 \mathrm{~h}$ before surgery, and drug concentrations were obtained using whole tissue homogenates, which measure total drug concentration, including extracellular, intracellular, and protein-bound and non-bound drug. Two early studies among healthy volunteers and patients with obstructive lung disease found that linezolid concentrations were much higher in epithelial lining fluid (ELF), as compared to blood [11, 12]. A subsequent study among patients with ventilator-associated pneumonia, found penetration in ELF of approximately $100 \%$ [13]. These findings highlight the challenges associated with inferring linezolid lung tissue concentrations from ELF measurements among patients with tuberculosis, and/or from data

TABLE 1 Free serum and tissue linezolid concentrations and lung to serum drug concentration ratios among patients with drug-resistant pulmonary tuberculosis

\begin{tabular}{|c|c|c|c|c|c|c|}
\hline Patient & $\begin{array}{c}\text { Dose } \\
\mathrm{mg} \cdot \mathrm{kg}^{-1}\end{array}$ & $\begin{array}{l}\text { Free serum concentration at } \\
\text { time of resection }{ }^{\#} \mu \mathrm{g} \cdot \mathrm{mL}^{-1}\end{array}$ & $\begin{array}{l}\text { Non-diseased lung tissue } \\
\text { concentration } \mu \mathrm{g} \cdot \mathrm{mL}^{-1}\end{array}$ & $\begin{array}{l}\text { Diseased lung tissue } \\
\text { concentration } \mu \mathrm{g} \cdot \mathrm{mL}^{-1}\end{array}$ & $\begin{array}{l}\text { Diseased } \\
\text { lung/serum }\end{array}$ & $\begin{array}{c}\text { Non-diseased } \\
\text { lung/serum }\end{array}$ \\
\hline 1 & 9.23 & 7.73 & 10.24 & 7.09 & 0.92 & 1.32 \\
\hline 3 & 8.33 & 8.79 & 3.43 & 4.27 & 0.49 & 0.42 \\
\hline 4 & 7.50 & 7.24 & 2.03 & 1.30 & 0.17 & 0.27 \\
\hline 5 & 7.69 & 7.71 & 6.01 & 4.22 & 0.55 & 0.78 \\
\hline 8 & 10.53 & 10.54 & 4.97 & 2.75 & 0.26 & 0.47 \\
\hline Median & 8.33 & 7.77 & 3.85 & 3.56 & 0.49 & 0.41 \\
\hline
\end{tabular}

\footnotetext{
\# : free serum concentration=measured linezolid concentration $\times 0.69$.
} 
obtained from patients without tuberculosis disease, and stress the need for measurements at the site of disease.

Study limitations include a small cohort of patients deemed to be not responding well to treatment, and thus may not be representative of all patients with tuberculosis. We measured linezolid lung concentrations at only one point in time (ex vivo), and therefore could not measure key pharmacokinetic parameters, including tissue $\mathrm{AUC} / \mathrm{MIC}$ and time $>\mathrm{MIC}$. It is also unclear how probe placement variation might have affected the results.

While we found lower linezolid concentrations in the lung versus serum, concentrations in the lung were above the utilised MIC and MPC values in almost all patients. Regarding the clinical implications, our results suggest the cautious use of doses lower than $600 \mathrm{mg}$ in patients with severe tuberculous lung lesions.

Russell R. Kempker ${ }^{1}$, M. Tobias Heinrichs ${ }^{2}$, Ketino Nikolaishvili $^{3}$, Irina Sabulua ${ }^{3}$, Nino Bablishvili, Shota Gogishvili ${ }^{3}$, Zaza Avaliani ${ }^{3}$, Brent P. Little ${ }^{4}$, Adam Bernheim ${ }^{4}$, Hartmut Derendorf ${ }^{2}$, Henry M. Blumberg ${ }^{1,5}$, Sergo Vashakidze ${ }^{3}$ and Charles A. Peloquin ${ }^{2}$

${ }^{1}$ Division of Infectious Diseases, Dept of Medicine, Emory University School of Medicine, Atlanta, GA, USA. ${ }^{2}$ University of Florida, College of Pharmacy, Gainesville, FL, USA. ${ }^{3}$ National Center for Tuberculosis and Lung Disease, Tbilisi, Georgia. ${ }^{4}$ Dept of Radiology and Imaging Sciences, Emory University School of Medicine, Atlanta, GA, USA. ${ }^{5}$ Depts of Epidemiology and Global Health, Emory Rollins School of Public Health, Emory University, Atlanta, GA, USA.

Correspondence: Russell Kempker, Division of Infectious Diseases, Dept of Medicine, Emory University School of Medicine, 49 Jesse Hill Jr. Dr., Atlanta, GA 30303. E-mail: rkempke@emory.edu

Received: Aug 232017 | Accepted after revision: Nov 232017

Support statement: This work was supported in part by the National Institutes of Health Fogarty International Center (D43TW007124), National Institute of Allergy and Infectious Diseases (K23AI103044; R21AI122001), the Atlanta Clinical and Translational Science Institute (UL1TR000454), and the Emory University Global Health Institute. Funding information for this article has been deposited with the Crossref Funder Registry.

Conflict of interest: Disclosures can be found alongside this article at erj.ersjournals.com

The findings of this study have been presented in part at the 48th Union World Conference on Lung Health, Guadelajara, Mexico, October 13, 2017.

\section{References}

1 World Health Organization. Global Tuberculosis Report 2016. WHO.HTM/TB/2016.13. Geneva, World Health Organization, 2016.

2 Sotgiu G, Centis R, D'Ambrosio L, et al. Efficacy, safety and tolerability of linezolid containing regimens in treating MDR-TB and XDR-TB: systematic review and meta-analysis. Eur Respir J 2012; 40: 1430-1442.

3 Srivastava S, Magombedze G, Koeuth T, et al. Linezolid dose that maximizes sterilizing effect while minimizing toxicity and resistance emergence for tuberculosis. Antimicrob Agents Chemother 2017; 61: e00751-17.

4 Vashakidze S, Gogishvili S, Nikolaishvili K, et al. Favorable outcomes for multidrug and extensively drug resistant tuberculosis patients undergoing surgery. Ann Thorac Surg 2013; 95: 1892-1898.

5 Kempker RR, Barth AB, Vashakidze S, et al. Cavitary penetration of levofloxacin among patients with multidrug-resistant tuberculosis. Antimicrob Agents Chemother 2015; 59: 3149-3155.

6 Stalker DJ, Jungbluth GL. Clinical pharmacokinetics of linezolid, a novel oxazolidinone antibacterial. Clin Pharmacokinet 2003; 42: 1129-1140.

7 Kempker RR, Heinrichs MT, Nikolaishvili K, et al. Lung tissue concentrations of pyrazinamide among patients with drug-resistant pulmonary tuberculosis. Antimicrob Agents Chemother 2017; 61: e00226-17.

8 Schon T, Jureen P, Chryssanthou E, et al. Wild-type distributions of seven oral second-line drugs against Mycobacterium tuberculosis. Int J Tuberc Lung Dis 2011; 15: 502-509.

9 Rodriguez JC, Cebrian L, Lopez M, et al. Mutant prevention concentration: comparison of fluoroquinolones and linezolid with Mycobacterium tuberculosis. J Antimicrob Chemother 2004; 53: 441-444.

10 Kempker RR, Rabin AS, Nikolaishvili K, et al. Additional drug resistance in Mycobacterium tuberculosis isolates from resected cavities among patients with multidrug-resistant or extensively drug-resistant pulmonary tuberculosis. Clin Infect Dis 2012; 54: e51-e54.

11 Conte JE Jr, Golden JA, Kipps J, et al. Intrapulmonary pharmacokinetics of linezolid. Antimicrob Agents Chemother 2002; 46: 1475-1480.

12 Honeybourne D, Tobin C, Jevons G, et al. Intrapulmonary penetration of linezolid. J Antimicrob Chemother 2003; 51: 1431-1434.

13 Boselli E, Breilh D, Rimmele T, et al. Pharmacokinetics and intrapulmonary concentrations of linezolid administered to critically ill patients with ventilator-associated pneumonia. Crit Care Med 2005; 33: 1529-1533. 